\title{
Industrial ammonia gassing
}

\author{
M. WALTON \\ Poole Hospital, Middlesbrough, Teesside
}

\begin{abstract}
Walton, M. (1972). British Journal of Industrial Medicine, 30, 78-86. Industrial ammonia gassing. Seven cases of ammonia gassing are described with follow-up for five years of the six survivors and the post-mortem findings of the fatal case.

All the survivors attributed continuing symptoms to the gassing. The study failed to demonstrate permanent ill effects in the one case of mild exposure. Of the more serious cases one has stopped smoking and taken up physical training teaching. He now has above average lung function. Two serious cases who continued to smoke have the lung function abnormalities expected from their smoking. In the other two seriously exposed cases, who also continued to smoke, there is a persistent reduction in ventilation and gas transfer which seems to be due to the ammonia gassing.

The post-mortem findings in the fatal case showed acute congestion and oedema of the mucosa of the respiratory tract, the bronchial walls being stripped of their lining epithelium and the alveoli stuffed with red blood cells and oedema fluid.
\end{abstract}

Ammonia has always been an important industrial chemical. Before the second world war its traditional uses were in the manufacture of fertilisers, nitric acid, explosives, in refrigeration plants, and as a cleansing agent for household purposes. During and since the second world war, uses for ammonia have expanded enormously and it is now used in large amounts as the raw material in a variety of new processes. These include petrol refining and the making of plastics and synthetic fibres. Further, ammonia is a principal feedstock in the making of hydrocyanic acid, cyanides, and nitriles. As a result, plants making or handling liquid ammonia under pressure are widespread throughout all industrial countries and the transport of liquid ammonia by road and rail and by ship has seen a rapid and enormous increase.

Slot (1938) reported the clinical details of six young women gassed and burned with ammonia in an ice-cream factory. The main effects were burns to the eyes, skin, and mouth, and a persistent bronchitis. One patient died and at necropsy epithelial ulcers in the bronchi, acute laryngotracheitis, and bronchopneumonia were seen. Bronchospasm and anxiety neurosis were noted in the survivors.
Brille, Hatzfeld, and Laurent (1957) detailed minutely the clinical and functional follow-up of two patients with ammonia gassing. Both patients were bronchoscoped during the follow-up period and biopsy specimens showed ulceration and desquamation of the bronchial mucous membrane. They postulated that some inflammation persists, causing permanent airways narrowing with chronic obstructive airways disease.

Lepine and Soucy (1962) describe the physiological disturbances which followed the acute phase in a case of ammonia gassing. They consider that obliterative bronchiolitis leads to emphysema with loss of diffusing capacity.

Derobert, Proteau, and Caroff (1964) reported the post-mortem appearances of four workers who died from ammonia gassing. The lesions were acute tracheobronchitis with bronchial ulceration.

Levy, Divertie, Litzow, and Henderson (1964) reported four cases of ammonia gassing with near fatal respiratory changes but in their opinion no permanent disability resulted.

The process of regeneration of tracheal epithelium following severe damage was described by Wilhelm (1953) in rats after curettage by a closed technique. 
He outlined four stages: (1) thrombosis and inflammation; (2) regeneration of epithelium over the curetted surfaces from surviving islets and necks of surviving glands; (3) simple stratification of the new epithelium; (4) redifferentiation of the new epithelium with ciliation. The fibrin clot and cellular reaction proceeds rapidly in the first 12 hours and the clot breaks away when the regenerating epithelium undermines it in from 36 to 48 hours. The final redifferentiation of the epithelial cells into ciliated patterns was seen in 12 to 14 days and was complete in six weeks. Hers (1955) was able to confirm this in humans when studying the histopathology of the respiratory tract in influenza. He reported that the ciliated epithelium suffered necrosis with loss of the surface cellular layers down to the basal layer. This was followed by regeneration after the fourth day with first stratified squamous and subsequently ciliated epithelium at the end of one month.

With the increasing industrial use of ammonia, more accidents are likely to occur and it is important to establish whether an acute exposure does lead to permanent lung damage. In this paper four accidents involving altogether seven men are described. Studies to detect permanent lung damage were carried out.

\section{Material and methods}

The accidents occurred during the period January 1966 to November 1967 in an ammonia plant which is part of a giant chemical complex on the north bank of the river Tees. The circumstances are described in relation to the case histories and follow-up findings below.

The men were examined at yearly intervals following the accidents. In addition to a symptomatic enquiry and a brief physical examination a chest radiograph and the following tests were carried out. Forced expiratory volume and forced vital capacity were measured using either a Vitalograph or a Bernstein (Bernstein and Mendel, 1953) type spirometer. The mean of three readings was taken after two trial tests. The gas transfer factor was measured by the single breath method of Forster $e t$ al. (1955) using a Resparameter (Morgan). The results are a mean of three readings. All test results are shown as the mean of the uncorrected findings, and the predicted value for a man of the same age and height (Cotes, 1968) is shown for comparison. No ventilatory studies were available for these men before their accidents and the first tests were carried out between 1 and 10 months afterwards and therefore fail to show the maximal disability. Litigation on these cases was not complete when the study ended.

\section{Results}

The acute symptoms due to exposure were the same in all cases (Table 1). Ammonia is intensely hygroscopic and causes burning of exposed surfaces, especially the damp mucous membranes. It caused an intense searing pain in the mouth and throat, inhibiting breathing and causing a sense of impending doom. Bloodstained mucus started running from the nose and mouth, breathing was difficult, and there was a grunting cough and aphonia. The eyes smarted and were tightly shut, and tears poured from between spastic lids. Cyanosis developed quickly, and the exposed skin and mucous membranes swelled up and blistered. An obstructive stridor developed. Blisters occurred in the mouth, on the fauces, and on the skin of the face and hands; they coalesced and burst, bleeding and weeping serous fluid. The cornea appeared hazy in some men, while conjunctival blistering and injection were seen on parting the lids. Auscultation of the chest revealed moist sounds on inspiration with a marked expiratory wheeze. These abnormal sounds were most obvious in those patients in acute distress accompanied by tachycardia (Table 1).

Improvement in all survivors began in the 48-72 hour period with an increasingly productive cough and relief of the chest symptoms of tightness and difficulty in breathing. Strings of necrotic material appeared in the sputum. The volume of the sputum gradually diminished over the ensuing days, as did the cough pari passu with the improvement in exercise tolerance and general well-being.

There was remarkably little radiological abnormality associated with the severe exposure to ammonia gas. In only two men was there any evidence of radiological changes and these were ill-defined opacities at the base. These films were taken by portable apparatus during the acute phase of the obstructive dyspnoea and the quality is not good. They were interpreted as showing patchy collapse and consolidation which cleared completely within a day or so. In no case has a subsequent radiograph shown any abnormality. The diagnosis of early emphysema is difficult at the best of times during life, and in chronic obstructive airways disease is usually assumed to be present. In none of our patients was there clinical evidence such as barrelshaped chest, tympanitic percussion note, or absence of cardiac dullness. There was no radiological evidence to fit Simon's (1964) postulates of flattened diaphragm and increased transradiancy due to paucity of vessels.

All six survivors are back at work. Three are back at their old jobs and are not losing any time through illness. Two are employed away from fume and dust on sedentary duties. One man has changed his job and has trained to become a school teacher.

\section{The incidents}

1. The first accident occurred on 6 January 1966 when two men were engaged on valve maintenance at ground level. A vent stack (Fig. 1) filled up with pure liquid ammonia and overflowed so that liquid cascaded down 
TABLE 1

Summary of Clinical Findings in 6 Patients who survived Ammonia Gassing

\begin{tabular}{|c|c|c|c|c|c|c|c|}
\hline $\begin{array}{c}\text { Case } \\
\text { Age }(y r)\end{array}$ & $J o b$ & $\begin{array}{l}\text { Smoking habits } \\
\text { (cigarettes/day) }\end{array}$ & $\begin{array}{l}\text { Chest } \\
\text { history }\end{array}$ & Accident & Symptoms and signs & Treatment & $\begin{array}{l}\text { Returned to } \\
\text { work after: }\end{array}$ \\
\hline $\begin{array}{c}\text { W.T. } \\
24\end{array}$ & $\begin{array}{l}\text { Instrument } \\
\text { artificer }\end{array}$ & 15 & Nil & $\begin{array}{l}6 \text { Jan. } \\
1966 \\
\text { Heavy } \\
\text { exposure }\end{array}$ & $\begin{array}{l}\text { Dyspnoea, chest pain, } \\
\text { blepharospasm, burning } \\
\text { throat, blisters and } \\
\text { sloughs of oral mucosa } \\
\text { and exposed skin, } \\
\text { conjunctivitis, bronchitis }\end{array}$ & $\begin{array}{l}\text { Oxygen by mask, } \\
\text { local toilet to } \\
\text { burns, } \\
\text { hydrocortisone, } \\
\text { antibiotics, } \\
\text { antispasmodics }\end{array}$ & $\begin{array}{l}6 \mathrm{mth} \\
\text { (became a } \\
\text { student } \\
\text { teacher) }\end{array}$ \\
\hline $\begin{array}{r}\text { J.L. } \\
39\end{array}$ & $\begin{array}{l}\text { Maintenance } \\
\text { electrician }\end{array}$ & 15 & Nil & $\begin{array}{l}6 \text { Jan. } \\
1966 \\
\text { Heavy } \\
\text { exposure }\end{array}$ & $\begin{array}{l}\text { Dyspnoea, chest pain, } \\
\text { blepharospasm, burning } \\
\text { throat, extensive blisters, } \\
\text { tachycardia, moist } \\
\text { sounds both bases }\end{array}$ & $\begin{array}{l}\text { Oxygen, } \\
\text { local treatment, } \\
\text { hydrocortisone, } \\
\text { frusemide, } \\
\text { antibiotics, } \\
\text { antispasmodics }\end{array}$ & $3 \mathrm{mth}$ \\
\hline $\begin{array}{r}\text { L.S. } \\
42\end{array}$ & $\begin{array}{l}\text { Maintenance } \\
\text { fitter }\end{array}$ & 15 & Nil & $\begin{array}{l}27 \text { Sept. } \\
1967 \\
\text { Light } \\
\text { exposure }\end{array}$ & $\begin{array}{l}\text { Blepharospasm, } \\
\text { bronchospasm }\end{array}$ & $\begin{array}{l}\text { Oxygen, } \\
\text { eye washes, } \\
\text { oral washes }\end{array}$ & 3 days \\
\hline $\begin{array}{r}\text { S.S. } \\
39\end{array}$ & $\begin{array}{l}\text { Assistant } \\
\text { process } \\
\text { foreman }\end{array}$ & 15 & Nil & $\begin{array}{l}18 \text { Nov. } \\
1967 \\
\text { Heavy } \\
\text { exposure }\end{array}$ & $\begin{array}{l}\text { 'Lungs seized up', } \\
\text { blepharospasm, } \\
\text { pink frothy sputum, } \\
\text { cyanosis, bronchospasm, } \\
\text { blisters of skin and throat }\end{array}$ & $\begin{array}{l}\text { Oxygen, } \\
\text { local treatment, } \\
\text { hydrocortisone, } \\
\text { antibiotics, } \\
\text { antispasmodics }\end{array}$ & $5 \mathrm{mth}$ \\
\hline $\begin{array}{l}\text { N.S. } \\
39\end{array}$ & $\begin{array}{l}\text { Process } \\
\text { foreman }\end{array}$ & 15 & Nil & $\begin{array}{l}18 \text { Nov. } \\
1967 \\
\text { Heavy } \\
\text { exposure }\end{array}$ & $\begin{array}{l}\text { Pain in throat and eyes, } \\
\text { pink frothy sputum, } \\
\text { burns and blisters of face } \\
\text { and mouth, } \\
\text { bronchospasm }\end{array}$ & $\begin{array}{l}\text { Oxygen, } \\
\text { local treatment, } \\
\text { hydrocortisone, } \\
\text { antibiotics, } \\
\text { antispasmodics }\end{array}$ & $3 \mathrm{mth}$ \\
\hline $\begin{array}{l}\text { E.R. } \\
47\end{array}$ & $\begin{array}{l}\text { Process } \\
\text { worker }\end{array}$ & 20 & Nil & $\begin{array}{l}26 \text { Nov. } \\
1967 \\
\text { Very } \\
\text { heavy } \\
\text { exposure }\end{array}$ & $\begin{array}{l}\text { Tightness of chest, } \\
\text { blepharospasm, } \\
\text { bloodstained sputum, } \\
\text { gashed wound of leg }\end{array}$ & $\begin{array}{l}\text { Oxygen, } \\
\text { local treatment, } \\
\text { hydrocortisone, } \\
\text { antibiotics, } \\
\text { antispasmodics }\end{array}$ & $6 \mathrm{wk}$ \\
\hline
\end{tabular}

100 feet ( 30 metres) dousing the men. One man collapsed and was rescued in a few minutes by personnel wearing breathing apparatus. The other struggled clear of the cloud to reach the plant control room a few yards away. Both men were taken immediately to the well equipped works medical centre. W.T., a 24-year-old instrument artificer, was noted to have developed acute obstructive dyspnoea with wheezy stridor and deep cyanosis. There were blisters in the mouth and throat and the eyes were congested. He was transferred to the ear, nose, and throat hospital where the blisters were incised, saline dressings applied, and boracic eye washes given. Continuous oxygen, periods of steam inhalation, and injections of penicillin, 1 mega unit, were given. Digitalis, frusemide, and aminophylline were also prescribed. A chest radiograph showed no abnormality. Over the next 24 hours his cough became more productive, first with frothy white secretion followed by the expectoration of strings of mucosal debris. His voice which had been lost returned gradually but hoarseness persisted. In March 1968 he underwent chest investigation because of dyspnoea on exertion. Bronchoscopy and bronchography showed no abnormality but biopsy of the bronchial mucosa showed an excessive collagenization in the submucosal layer on histology. He stopped smoking and became a physical training teacher and his latest lung function tests are well above the predicted normal (Tables 2 to 4 ). The forced vital capacity, the forced expiratory volume in one second, and the transfer factor (single breath) measured over the ensuing five years were all recorded as higher than predicted normal values for him on each occasion.

Also gassed in this accident was J.L., a 39-year-old maintenance electrician. His previous health had been good but he smoked 15 cigarettes per day. When he was enveloped in the ammonia cloud he struggled to the control room inhaling several breaths of the gas. He was immediately taken to the works medical centre where firstaid measures were given as for the first patient. Later he was transferred to the ear, nose, and throat hospital. Increasing respiratory difficulty developed with deep cyanosis and crepitations at both lung bases. His jugular venous pressure was raised, he had a tachycardia of 130 per minute, and an electrocardiogram showed signs of atrial strain. The chest radiograph showed basal congestive changes. It was decided to do a tracheostomy to bypass the faucial oedema and as the surgical team was assembling treatment was continued in a steam tent. However, following the expectoration of stringy sputum his condition improved so much that tracheostomy was not necessary. The burns on the cornea and blisters of the face and mouth soon improved. Other treatment given in hospital included continuous oxygen, digitalis, 


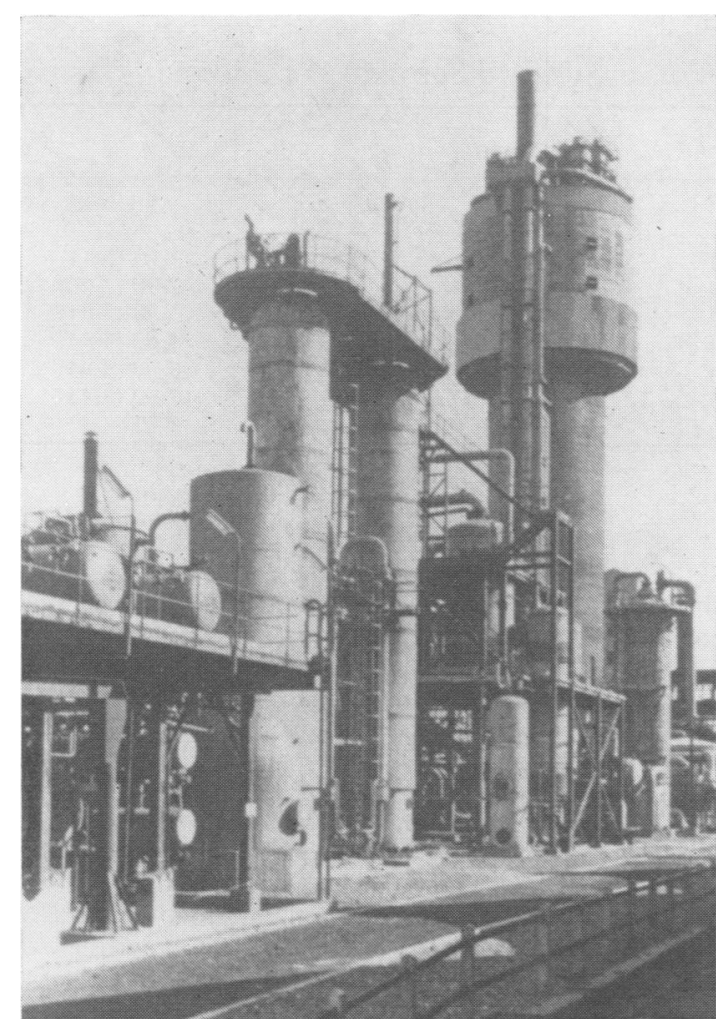

FIG. 1. General view of the ammonia plant with raised gantry, vent stacks, and vessels.

frusemide, aminophylline, and penicillin. His aphonia lasted about 10 days and was replaced by a slowly resolving hoarseness. He returned to work after three months and has maintained a good attendance record except for about three weeks lost work per year because of bronchitis. He still smokes at the same rate. His lung function tests are detailed in Tables 2 to 4 . Both the forced vital capacity and the expiratory volume in one second show considerable reduction below the predicted normal figures. Both tests showed improvement up to the second year but no change since then. On the other hand, the transfer factor improved to nearly normal after the second year and has remained at this better level.

2. On 27 September 1967 a 42-year-old maintenance fitter (L.S.) dismantled a valve on the ammonia liquor high pressure line. Gas flow was inadvertently resumed and he was exposed to a heavy concentration of ammonia. Before he could extricate himself he inhaled some of the gas. He was taken for treatment to the works medical centre where it was noted that he had a burn on the left eye. Treatment with oxygen, eye washes, and oral toilet was given and the patient was allowed to go home. He returned to work almost immediately, is now back at his old job, and maintains an excellent attendance record. He smokes 15 cigarettes per day. Lung function measurements since the accident are as detailed in Tables 2 to 4 . The ventilation tests all showed a better than predicted figure for this patient. The transfer factor remains uniformly depressed and this could be associated with his cigarette smoking.

3. On 18 November 1967 two men working on a gantry 7 feet $(2 \cdot 1 \mathrm{~m})$ above ground level were doused with ammonia liquor from a tower 130 feet $(39.5 \mathrm{~m})$ high. S.S. was a 39-year-old assistant process foreman and, although burnt and suffering from acute chest pain, he struggled down the gantry ladder and collapsed in the nearby control room. He was taken immediately to the medical centre where it was noted that he was dyspnoeic, coughing up pink frothy mucus, and had severe burns of the face, mouth, and hands. After first-aid measures as detailed for the previous cases he was transferred to hospital. There it was noted that he had weeping eyes and red, congested, and oedematous fauces. There was no evidence of bronchospasm on auscultation and the chest radiograph was normal. He had treatment with oxygen, hydrocortisone, aminophylline, frusemide, and oxytetracycline. He was discharged home on 24 November 1967. He returned to work on 28 February 1968 but has a poor work record, being off work with bronchitis six weeks each year. He has smoked 15 cigarettes per day for many years and has a persistent morning cough with sputum. His duties are largely office work and he maintains that he gets very short of breath on climbing. Night shifts he finds very distressing. Serial lung function tests show no real change in either ventilation or transfer

TABLE 2

Forced Vital Capacity on Annual Follow-up of 6 Survivors of ammonia Gassing

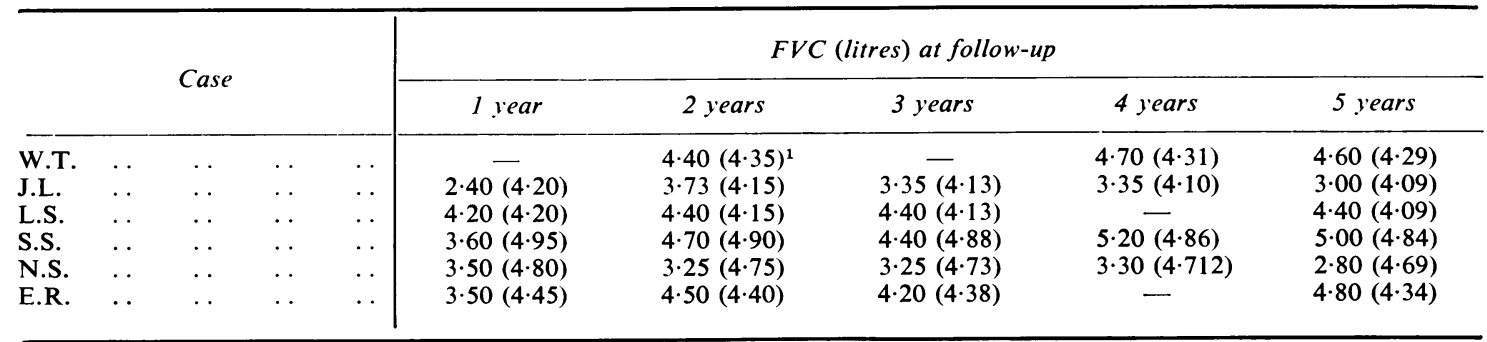

${ }^{1}$ Predicted values in parentheses 
TABLE 3

Forced Expiratory Volume in 1 Second at Annual Follow-up of 6 Survivors of Ammonia Gassing

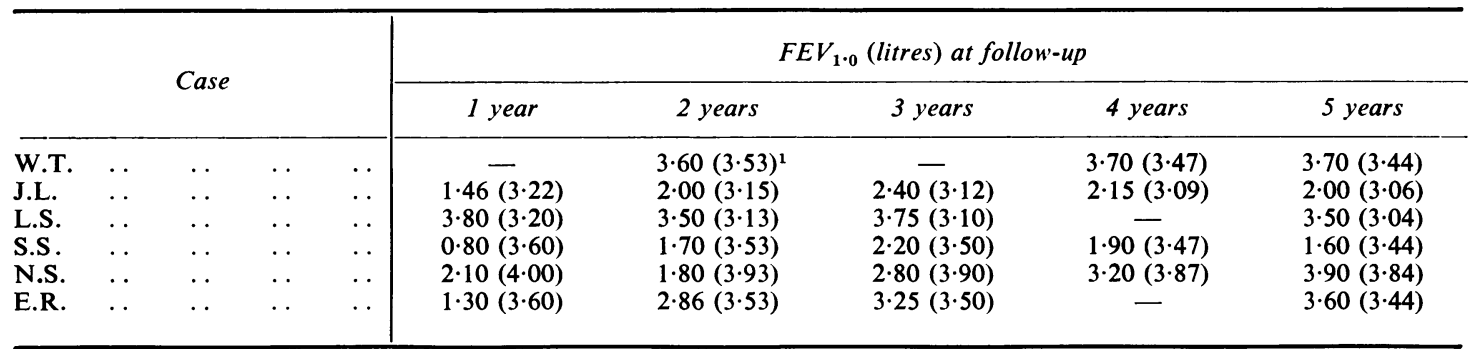

${ }^{1}$ Predicted values in parentheses

factor. Tables 2 to 4 detail the figures of the annual follow-up examination. After the first year the forced vital capacity reaches and holds the predicted normal level. On the other hand, the forced expiratory volume in one second test shows moderate obstructive airways disease. The transfer factor remains below the predicted normal figure for the patient.

The other man involved in this accident was N.S., a 39-year-old process foreman. He too negotiated the gantry steps to the ground before getting out of the gas cloud. He felt his lungs 'seize up', his eyes burned, and he thought he was going to die. He collapsed before reaching the control room and was rescued by personnel wearing masks. He was taken immediately to the medical centre where first-aid measures were applied before his transfer to hospital. Intense local spasm of the lids, chemical burns of the eyes, mouth, face, and throat were noted. He was coughing up pink frothy mucus. A chest radiograph was clear, there was no bronchospasm, and treatment was given with oxygen, hydrocortisone, aminophylline, and oxytetracycline. He was able to leave hospital after six days and returned to work after two months. He was back at his normal duties after five months. He still smokes 20 cigarettes per day. He sought medical advice for depression and lassitude and tranquillizers were prescribed. It is interesting that occasionally all his food tastes of a mixture of onions, pork, beef, and chicken. Serial lung function tests (Tables 2 to 4 ) show progressive improvement in the ventilation but a consistent depression of the transfer factor.

4. On 26 November 1967 two men were struck by a cloud of ammonia released when retaining bolts sheared and a compressor pump burst when working at 220 atmospheres pressure (Fig. 2). One man (E.T.) died in the accident. The other man (E.R.), a 47-year-old process worker, had to run some 50 yards $(45 \mathrm{~m})$ before he reached clean air. In his headlong flight he gashed his leg. When he was seen at the medical centre he had burns of the eyes, throat, and mouth and complained of tightness of the chest. He felt as if his chest was on fire and he had coughed up bloodstained frothy mucus. The large blisters in the mouth burst and bled. His leg wound was also burning and painful and there was a large blister over the left heel. After first-aid treatment he was transferred to hospital where he was given oxygen, hydrocortisone, aminophylline, and oxytetracycline. He stayed in hospital for eight days. His voice, which was absent on admission, gradually returned with the development of a loose cough. He felt short of breath and could walk only 20 yards $(18 \mathrm{~m})$ on the level at first, but this gradually improved and he returned to work six weeks later. $\mathrm{He}$ had smoked 20 cigarettes per day for 20 years but since his return to work he has maintained a good attendance record. He feels he is still limited on exertion compared to before the accident, but his disability pension has now stopped. Lung function tests (Tables 2 to 4 ) have shown

TABLE 4

Transfer factor at Annual follow-up of 6 Survivors of Ammonia Gassing

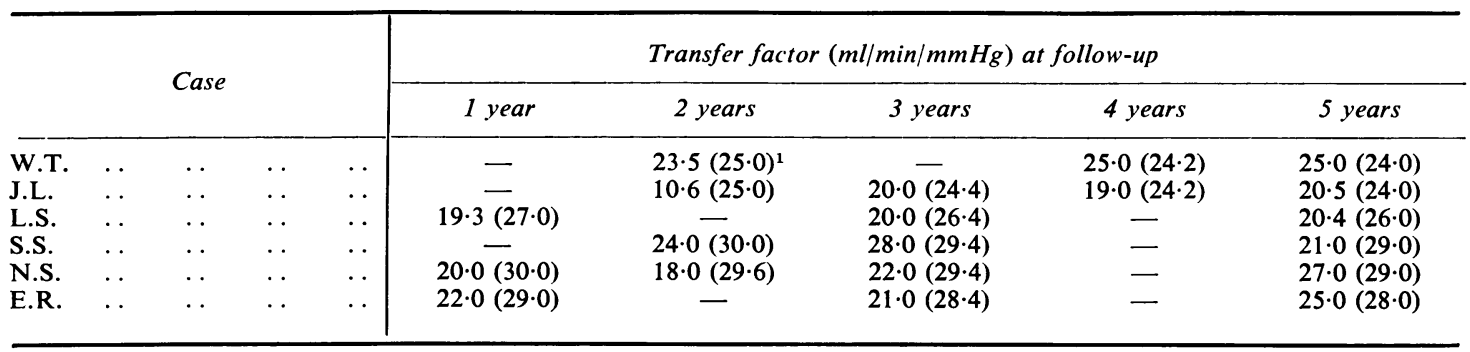

${ }^{1}$ Predicted values in parentheses 


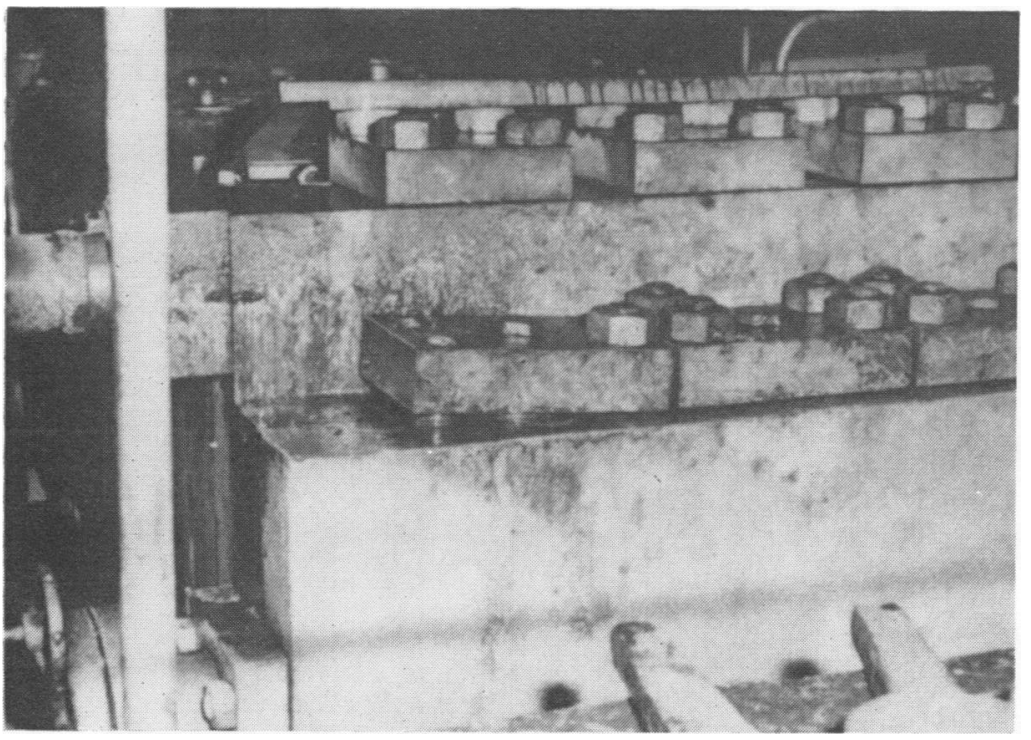

FIG. 2. A view of the fractured compressor pump when the bolts sheared, releasing ammonia at 220 atmospheres pressure.

a gradual improvement in the ventilatory ability of this patient on the annual review. The transfer factor, on the other hand, has remained unchanged at a low normal level.

The clinical data of these patients are summarized in Table 1.

The post-mortem findings in E.T., who died in this incident, showed extensive oedema and burns affecting the mouth, fauces, trunk, arms, and upper part of the back. The airway at the larynx is almost blocked (Fig. 3). The lungs were greatly distended and congested. On histological examination the lungs showed acute congestion and oedema. The blood vessels were engorged; this is most noticeable in the capillaries of the alveolar walls and has led to effusion of blood and oedema into the alveoli (Fig. 4). The bronchial walls are stripped of their epithelial lining except where a few damaged cells remain in the larger air passages (Fig. 5). Some smaller bronchi contain plugs of debris which include epithelial cells, red blood cells, and dust cells (Fig. 6). No infiltration of the walls of the air passages by polymorphs or lymphocytes has occurred.

\section{Discussion}

It was obvious from the symptoms that the degree of airways obstruction at the time of the accidents was extremely severe. The rate of recovery was rapid at first and then continued more gradually.

Although no pre-exposure readings were available, it can be seen from the readings in Tables 2 to 4 that recovery was still continuing at the time of the first tests which were done 2 to 10 months after the accidents.

The forced vital capacity findings (Table 2) showed a low reading on the first occasion with



FIG. 3. Arrow indicates the airway slit reduced by laryngeal oedema due to ammonia gassing. 




FIG. 4. Alveoli containing red blood cells and exudates. The alveolar sac pattern is maintained. H. and E. $\times 70$.



subsequent improvement in all but one of the men. This man (L.S.) was the one who had had the least severe exposure. The man (J.L.) with the most severe acute illness (in whom tracheostomy was considered) had a $40 \%$ loss of forced vital capacity at the first test. He was still $25 \%$ below predicted after five years, having reached a peak improvement at the end of two.

The forced expiratory volume findings (Table 3 ) are similar to the forced vital capacity and perhaps this is the best single test for following the airways disturbance in such patients. By this test the most severely affected patient (J.L.) has a reading less than $50 \%$ of expected on the first test and reached a peak $(77 \%)$ after three years. No abnormality was found in the man with least exposure and in the others the maximum improvement was achieved by the end of three years. In one man (S.S.) there is continued evidence of airway obstruction with low forced expiratory volume after the forced vital capacity had returned to predicted normal.

The transfer factor findings (Table 4) show similar changes to the ventilation tests. The results are affected by airways obstruction which may in turn

FIG. 5. The tracheal mucous membrane is disrupted and shed down to the cartilage. H. and E. $\times 14$. 


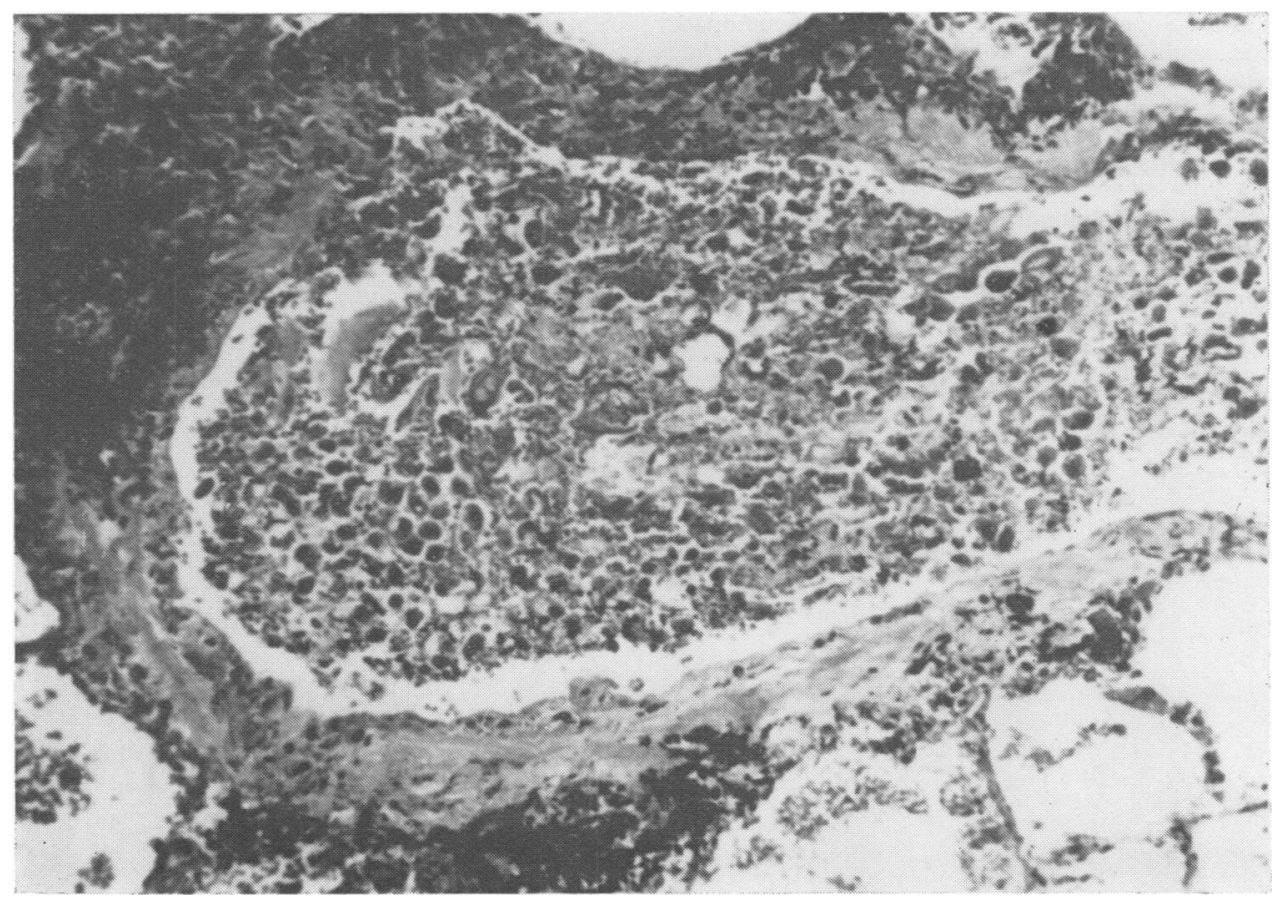

FIG. 6. A terminal bronchiole crammed with exudates, dust cells, and mucous membrane debris. H. and E. $\times 70$.

be due to smoking (Wilson, Meador, Jay, and Higgins, 1960; Martt, 1962). All the men smoked 15 to 20 cigarettes a day up to the time of their accidents and only one (W.T.) gave up smoking. The rest continued at their previous levels. The four severely exposed men who continued to smoke show a persistent reduction in transfer factor; in two (N.S. and E.R.), and in the man with less serious exposure (L.S.), this is no more than would be expected in smokers. In the other two men there is a persistent defect which seems greater than can be accounted for by the smoking but this test can be disturbed by eating (Cotes, 1968) and variation in the time of day (Lawther, Brooks, and Waller, 1970) so that it is difficult to interpret on so few readings.

This study shows that a severe acute exposure to ammonia gas does leave evidence of airways damage and reduced gas transfer for up to three years. After that persistent abnormalities were found in those who continued to smoke although they were able to continue in full-time employment. In the presence of lung damage due to smoking it is difficult to determine whether acute exposure to ammonia causes permanent lung damage.

My thanks are due to Dr. E. L. Knowles and Dr. J. T. B. Bain of ICI Billingham, to Dr. E. W. Walton for the pathological reports and photographs from the fatal: case and to the hospital staff.

\section{References}

Bernstein, L., and Mendel, D. (1953). A spirometer which can be used at high respiratory rates. Journal of Physio$\log y, 119,3 \mathrm{p}-4 \mathrm{p}$.

Brille, D., Hatzfeld, C., and Laurent, R. (1957). Pneumopathies professionelles silicose excéptee. IV. Bronchite chronique emphysème et professions; emphysème pulmonaire après inhalation de vapeurs irritantes; ammoniaque en particulier. Archives des Maladies Professionnelles, de Médecine du Travail et de Sécurité Sociale. 18, 320-336.

Cotes, J. E. (1968). Lung Function: Assessment and Application in Medicine, 2nd ed. Blackwell, Oxford.

Derobert, L., Proteau, J., and Caroff, J. (1964). Etude anatomique de quatre cas d'intoxication aigue par inhalation de gaz ammoniac. Annales de médecine légale, criminologie, police scientifique et toxicologie, 44, 362-366.

Forster, R. E., Cohn, J. E., Briscoe, W. A., Blakemore, W. S., and Riley, R. L. (1955). A modification of the Krogh carbon monoxide breath holding technique for estimating the diffusing capacity of the lung; a comparison with three other methods. Journal of Clinical Investigation, $34,1417-1426$.

Hers, J. F. (1955). The Histopathology of the Respiratory Tract in Human Influenza. Leiden, Stenfert-Kroese.

Lawther, P. J., Brooks, A. G. F., and Waller, R E (1970).

$\Delta$ ! Respiratory function measurements in a cohort of medical students. Thorax 25, 172-177. 
Lepine, C., and Soucy, R. (1962). The bronchopneumopathy of toxic origin. Physiopathological development. Union médicale du Canada, 91, 7-11.

Levy, D. M., Divertie, M. B., Litzow, T. J., and Henderson, J. W. (1964). Ammonia burns of the face and respiratory tract. Journal of the American Medical Association, 190, 873-876.

Martt, J. M. (1962). Pulmonary diffusing capacity in cigarette smokers. Annals of Internal Medicine, 56, 39-45.

Simon, G. (1964). Radiology and emphysema. Clinical Radiology, 15, 293-306.
Slot, G. M. J. (1938). Ammonia gas burns. Lancet, 2, 13561357.

Wilhelm, D. L. (1953). Regeneration of tracheal epithelium. Journal of Pathology and Bacteriology, 65, 543-549.

Wilson, R. H., Meador, R. S., Jay, B. E., and Higgins, E. (1960). The pulmonary pathologic physiology of persons who smoke cigarettes. New England Journal of Medicine, 262, 956-961.

Received for publication August 24, 1972. 